\title{
Dijitalleşme Çağında İşyerinin Değiş̧imi: Sebepleri ve Sonuçları
}

\author{
Change of the Workplace in the Age of Digitalization: Causes and Consequences
}

\author{
ABDULAH EROL ${ }^{*}$ \\ * Dr., İstanbul University, Faculty of Economics, Department of Labour Economics and Industrial \\ Relations, Beyazit/İstanbul, Turkey, E-mail: abdullah.erol@istanbul.edu.tr \\ (D) https://orcid.org/0000-0003-1018-1602
}

Öz: Dijitalleşmenin iş hukuku alanındaki en önemli etkilerinden birisi, işin belirli bir fiziksel mekânda görülmesi zorunluluğunu ortadan kaldırmış olmasıdır. Bu makalede, dijitalleşmenin etkisiyle ortaya çıkan değişimin neden olduğu birtakım güncel hukuki problemler ele alınmakta ve bunların çözümüne yönelik önerilerde bulunulmaktadır. Artık pek çok iş sanal platformlar veya internet üzerinden oluşturulan ortamlar sayesinde herhangi bir yerde yapılabilmektedir. Sanal işyerinde çalışmanın olumlu yönleri bulunsa da özellikle iş hukuku alanında içinden çıkılması zor sorunların doğmasına sebep olmaktadır. Telekomünikasyon alanındaki teknolojik gelişmelerin sonucunda doğan kitle çalışması ve kitle kaynak kullanımı gibi yeni çalışma şekilleri, işyerini sanallaştırmış ve iş yasalarında klasik işyeri kavramı üzerine tesis edilen pek çok düzenlemenin uygulanamaz hale gelmesine sebep olmuştur. Bağımlilık unsurundaki aşınmanın doğurduğu bu durumun çağın ihtiyaçlar da dikkate alınarak geliştirilecek yeni yorum yöntemleri ve oluşturulacak yeni kavramlarla aşılması mümkün ve gereklidir. Temel amacı işçi ve işveren arasında hakkaniyetli bir ortam oluşturmak olan iş hukukunun bu gelişmeyi göz ardı etmesi ve işyeri kavramındaki değişimin çalışanların haklarını ortadan kaldıracak şekilde kullanılmasına kayıtsız kalması mümkün değildir.

Anahtar kelimeler: Dijitalleşme, İsyeri, Kitle çalışması, Kitle kaynak kullanımı, Esnek ekonomi

Abstract: One of the most important effects of digitalisation in the field of labor law is that it eliminates the obligation to do the job in a specific physical space. Many jobs can now be done anywhere, thanks to virtual platforms or environments created over the internet. Although there are positive aspects of working in the virtual workplace, it causes problems that are difficult to overcome, especially in the field of labor law. New ways of working such as crowdwork and crowdsourcing, which emerged as a result of technological developments in the field of telecommunications, virtualized the workplace and caused many regulations established on the classical workplace concept in labor laws to become inapplicable. It is not possible for labor law, whose main purpose is to create an equitable environment between the employee and the employer, to ignore this development and to remain indifferent to the use of the change in the concept of the workplace in a way that will abolish the rights of the employees.

Keywords: Digitalisation, Workplace, Crowdworking, Crowdsourcing, Gigeconomy 


\section{Giriş}

Çalışma hayatının her kademesine önemli etkilerde bulunan dijitalleşme, rekabeti kutsayan ve kâr etmeyi temel amaç olarak gören neo-liberal anlayışın elinde kullanışlı bir araç haline gelmiştir. Öncelikli amacın kâr etmek olduğu ve sosyal ilişkilerin zayıfladığı bir çalışma ortamında, başarının yalnızca elde edilen kâr üzerinden değerlendirilmesi, doğal olarak işçi ve işyeri için yapılan harcamaların da maliyet unsuru olarak görülmesi sonucunu doğurmaktadır. Bunun neticesinde de maliyetleri azaltmak adına işverenler tarafından her geçen gün yeni “çözümler” üretilmektedir. Ancak söz konusu çözümler, işletmenin varlığını pekiştiren ve ayakta kalmasını sağlayan diğer unsurları yeteri kadar dikkate almadığından, yeni sorunların doğmasına yol açmaktadır.

Tarihsel süreçte işverenlerin kâr amacıyla, öncelikle işyerini daha verimli kullanmayı sağlayacak ve maliyetleri miktar olarak değilse de, oransal açıdan düşürecek yöntemleri kullandıkları görülmektedir. Kısmi süreli iş sözleşmesi, bu amaçla kullanılan yöntemlerin öncülerindendir. En eski esnek istihdam biçimlerinden birisi olan kısmi süreli iş sözleşmesinde, işyerinin mevcut kapasitesini geliştirmeksizin ve işyerine herhangi ek bir harcama yapılmaksızın daha fazla sayıda işçi istihdam ederek daha fazla kâr elde edilmeye çalışılmıştır. Bu yöntem, işgücü arzının talepten fazla ve işçilik maliyetlerinin düşük olduğu bir ortamda epeyce etkili olmuştur. Ancak işgücü arz ve talebinin dengelenmesiyle birlikte işçilik maliyetlerinin artması, işyerinde verimliliğin sağlanmasının yanında başka yöntemlerin bulunmasını gerektirmiştir. Zira işyeri ne kadar verimli kullanılırsa kullanılsın, elbette ki bu verimin de bir sınırı bulunmaktadır. Bu sınırın ötesine geçebilmek amacıyla, işyerinin ifade ettiği anlamın ve işçi/bağımlı çalışan kavramının içeriğinin değiştirilmesi hedeflenmiştir.

Telekomünikasyon alanındaki teknolojik gelişmeler ve dijitalleşme, iş hukukunun temel kavramlarının değiştirilmesi ve işverenler açısından maliyet olarak görülen unsurların ortadan kaldırılabilmesine önemli katkılar sağlamıştır. Çalışanlar açısından güvencesiz çalışmayı ve daha düşük bir yaşam standardına sahip olmayı ifade eden bu değişim, hem hukuki boşlukların doğmasına hem de sosyal dengesizliklerin yaşanmasına sebep olmaktadır. Bu çalışmada, Türkiye'de çoğunlukla sosyal politikanın konusu olarak görülen söz konusu değişimin, esasında iş hukuku boyutunun da büyük önem arz ettiği ve bu manada iş hukukunun da konusu olduğu ortaya konulmaya çalışılmıştır. Bağımlılık unsurunda ve iş hukukunun temel kavramlarında yaşanan değişime ilişkin Avrupa'da ve Amerika'da yüz yılı aşkın bir geçmişi bulunan yoğun tartışmalar, Türkiye'de aynı ölçüde gündeme gelmemektedir. Oysaki özellikle 1980'lerden itibaren çalışma hayatında değişimin çok hızlı bir şekilde yaşandığı Türkiye' de, iş sözleşmesinin bağımlılık unsurundaki ve iş hukukunun temel kavramlarındaki aşınmaya hukuki ve sosyal çözümlerin oluşturulması, toplumsal düzenin korunması bakımından büyük önem arz etmektedir. Bu bağlamda makale kapsamında, teknolojik gelişmeler neticesinde ortaya çıkan yeni çalışma şekilleri, bu çalışma şekillerinin bağımlılık unsuruna, işyeri kavramına ve işyeri kavramını temel alan hukuki düzenlemelere etkileri ele alınmaktadır.

\section{İşyeri Kavramında Yaşanan Değişim ve Bu Değişimin Sebepleri}

Fabrika tarzı üretimi öngören Fordist-Taylorist üretim modelinde, işçinin belirli bir işyerinde sözleşme konusu işi belirli çalışma sürelerinde, tek bir işverenin emir 
ve talimatları doğrultusunda yapması öngörülmektedir. Tipik iş olarak tanımlanan bu çalışma şekli, fabrika tarzı üretimden uzaklaşılmasıyla birlikte dönüşüme uğramış, sabit bir işyerinde çalışan işçilerin sayısı esnekleşme ve uzaklaştırma stratejileri kapsamında giderek azalmıştır ${ }^{1}$. İşyeri dışından kaynaklanan etkilere daha açık hale gelen işçilerin korunması zorlaşmış, buna karşın işverenlerin işçilere karşı (ekonomik üstünlük, bilgiye erişme ve kullanabilme vb.) avantajları daha da pekişmiştir. Bu dönüşüm, iş hukukunun değişmesini zorunlu hale getirmiş, yeni çalışma biçimleri ile oluşturulan çalışma ortamında işçi ve işveren arasındaki dengenin sağlanması bakımından yeni yasal düzenlemelerin yapılmasını gerektirmiştir.

İşverenin kurduğu iş organizasyonu içinde bulunan işyeri dışında çalışmayı öngören pazarlamacılık, birden fazla işyerinde çalışmaya fırsat veren kısmi süreli iş sözleşmesi, farklı işverenlere ait işyerlerinde çalışma zorunluluğu doğuran ödünç iş ilişkisi gibi esnek çalışma biçimleri, işyeri kavramının da yeniden tanımlanması zorunluluğunu doğurmuştur. Zira işçi ve işveren tarafından işyerinin, sözleşme konusu işi yapmak için kurulan işyerinden farklı bir yer olarak kararlaştırılabildiği çalışma modelleri, işyeri üzerinde temellenen pek çok yasal düzenlemenin uygulanmasında sorunlar oluşturmuştur. Ortaya çıkan yeni çalışma şekilleri, öncelikli olarak işçilerin sorunlarını çözmeye değil de, işletmelerin verimlilik seviyelerini ve kâr oranlarını arttırmaya odaklandığından, işçiler bakımından yeni ve hayâtî sorunlar doğurmuştur. Örneğin, sabit bir işyeri anlayışı üzerine temellenen çalışma ilişkilerinde ve iş sözleşmelerinde, işyeri dışında yapılan çalışmalarda iş sağlığ 1 ve güvenliği tedbirlerinin nasıl alınacağı ve işverenlerin sorumluluğunun nasıl düzenleneceği önemli sorun alanları arasında yer almaktadır².

İşyeri kavramında değişiklik yapılması ihtiyacı doğuran bir diğer gelişme de, işçinin işyerinden uzaklaştırılmasını ve işyeri dışında çalıştırılmasını öngören uzaklaştırma stratejilerinin doğması ve yaygınlaşması olmuştur. İletişim ve haberleşme alanındaki teknolojik gelişmelerin bir neticesi olarak gündeme gelen uzaklaştırma stratejileri, işyerini mümkün olduğunca küçülterek işyerinden kaynaklı maliyetleri azaltmayı hedeflemektedir ${ }^{3}$. Bu sebeple, işçilerin belirli bir işyerinde değil de teknolojinin getirdiği imkânlar kullanılarak neredeyse her yerde çalıştırılması artık çalışma hayatında yerleşmiş bir uygulama halini almıştır. Hem eskiden beri uygulanan esnek çalışma hem de teknolojik gelişmelerin doğurduğu uzaktan çalışma biçimleri, tipik iş ve işyeri kavramlarının işçilerin korunma ihtiyaçları göz önünde tutularak yeniden tanımlanmasını zorunlu kılmıştır. Bu ihtiyacı gören Türk kanun koyucusu, diğer ülkelerdekine paralel bir şekilde işyerini tek ve belirli bir yer olmaktan çıkarıp, işin yapıldı̆̆ı ve iş organizasyonu kapsamında yer alan her yer olarak kabul etmiştir (İş K. m. 2/II, III). Ancak bu kabul de kendi içerisinde sorunlar barındırmaktadır. Örneğin, mülkiyet hakkına veya üzerinde tasarrufta bulunma yetkisine sahip olmadığı bir yerde işçisi iş kazasına uğrayan işverenin iş sağlığı ve güvenliğine ilişkin tedbirleri almamaktan kaynaklanan sorumluluğu, söz konusu kabulün doğurduğu önemli bir sorundur. Zira bu durumda işvereni iş kazasından sorumlu tutmak hakkaniyete aykırı olacak, fakat tutmamak da işçinin hak kaybına

\footnotetext{
${ }^{1}$ Heather Hamblin, “Employees' Perspectives On One Dimension Of Labour Flexibility: Working At A Distance”, Work, Employment \& Society, 9/3 (1995), s.477-478.

${ }^{2}$ Richard Heeks, "Decent Work and the Digital Gig Economy: A Developing Country Perspective on Employment Impacts and Standards in Online Outsourcing, Crowdwork, etc", Development Informatics Working Paper Series, Centre for Development Informatics Global Development Institute, Working Paper No. 71, 2017, s.71.

${ }^{3}$ Hamblin, "Employees'Perspectives", s.478.
} 
uğramasına yol açacaktır. Bunun gibi pek çok sorunu çözmede yetersiz kalan mevcut işyeri tanımının, günün ihtiyaçlarını karşılayacak şekilde yeniden yapılması gerekmektedir.

\section{İşyerinin Geleceği: Sanallaşma}

\section{Sanal İşyeri}

Belirli bir işyeri olmaksızın veya belirli bir işyeri bulunmakla birlikte, işverenin kurduğu ve asıl işin yapıldığı işyerinden farklı bir yerde, internet temelli uygulamalar sayesinde yapılan çalışmalar genel olarak uzaktan çalışma, bu çalışmanın yapılmasını sağlayan platformlar "sanal işyeri" olarak adlandırılmaktadır". Sanal işyerleri, işverenlere işçilerini görmeden onlara emir- talimat verebilme imkânı sağlamakta, işlerini daha az maliyetle ve daha verimli bir şekilde sürdürebilmelerini mümkün kılmaktadır ${ }^{5}$. Zira sanal işyerleri, işin yapılması için fiziksel mekânlara duyulan ihtiyacı ve bu mekânlar için yapılması gereken harcamaları ortadan kaldırmakta; buna karşın işçilerin her an çalışabilir hale getirilmesi ve gerektiğinde yeni işçilerin kolayca bulunabilmesi gibi pek çok etken sayesinde verimlilik seviyesini artırmaktadir.

Sanal işyeri, işin yapılması ve işin yürütülmesi bakımından önemli değişiklikler ortaya çıkarmıştır. Özellikle, araç-gereç ihtiyacı bulunmayan, yalnızca bilgisayarın kullanıldığ büro işlerinde sanallaşma oldukça yoğun bir şekilde tercih edilmekte ve her geçen gün daha da yaygınlaşmaktadır ${ }^{6}$. Büro işlerinde, esasında fiziksel bir mekânın varlığı, işin yapılması bakımından zorunlu değildir. Dijitalleşme öncesinde işverenler, yönetimi kolaylaştırma ve verimliliği artırma bakımından daha kolay kontrol edebilecekleri bir işyerinin varlığına ihtiyaç duymuşlardır; ancak dijitalleşme sayesinde işçileri kontrol etme imkânı çok daha fazla geliştiğinden, fiziksel bir mekâna duyulan ihtiyaç da ortadan kalkmıştır.

İşyerinin sanallaşması, esnekleşme ve teknolojik gelişmelerin bir sonucu olmakla birlikte, aynı zamanda bunların sebebi olarak da nitelendirilebilecektir. İşverenlerin maliyetleri azaltmak amacıyla sürekli yeni üretim modelleri ve istihdam biçimleri bulma çabaları yeni esnek çalışma modellerinin üretilmesine ve teknolojinin de bunlara imkân sağlayacak şekilde gelişmesine ortam hazırlamaktadır. Sanal işyeri ve sanallaşma kavramları etrafında şekillenen gig economy, kitle kaynak kullanımı (crowdsourcing) ve kitle çalışması (crowdworking) kavramları, sanallaşmanın hem sebep hem de sonuç olmasına en iyi örneklerdir. Zira bu kavramlar, bir yandan çalışanların işyerinden uzakta, web tabanlı uygulamalar kullanarak çalışmalarını sağlamakta, diğer yandan bu istihdam biçimini sağlamlaştırmak ve devamını sağlamak için yeni teknolojilerin geliştirilmesine önayak olmaktadır.

Sanal işyerleri, işçiler ve işverenler açısından pek çok avantajlar barındırmaktadır. Nitekim kitle kaynak kullanımı, kitle çalışması gibi yeni çalışma modelleri anlatılırken de bu avantajlardan sıklıkla bahsedilmektedir. Ancak, yaşanan süreç, Türkiye örneği dikkate alındığında, esnek çalışmanın hızlı bir şekilde yaygınlaştığı 1980 sonrasındaki dönemle büyük benzerlikler taşımaktadır. Nitekim o dönemde

\footnotetext{
${ }^{4}$ Wayne F. Cascio, "Managing a Virtual Workplace", Academy of Management Executive, 14/3 (2000), s.81.

${ }^{5}$ Cascio, "Managing a Virtual Workplace", s.82.

${ }^{6}$ Christophe Degryse, Digitalisation of the Economy and its Impact on Labour Markets, Brüksel: European Trade Union Institute, 2016, s.53.
} 
de esnek çalışmanın yaygınlaşmasını sağlamak amacıyla, sağladığı avantajlar üzerinde sıklıkla durulmuş, fakat dezavantajlarından aynı ölçüde bahsedilmemiştir. İlerleyen zamanlarda, esnek çalışma türlerinin işçilerin çalışma koşullarında ve sendikal haklarını kullanmada yaşadıkları sorunların daha da derinleşmesine yol açtığı görülmüştür. Esnek çalışmanın daha ileri bir sürümü olarak nitelendirilebilecek sanallaşma ve teknolojik imkânlarla desteklenen uzaklaştırma stratejileri bakımından da büyük ölçüde benzer bir süreç işlemektedir.

\section{Sanal İşyeri Üzerinde Temellenen Yeni Kavramlar \\ Kitle Çalışması (Crowdworking)}

Rekabet ortamının küçük işletmeler lehine düzelmesini ve iş hayatında daha demokratik bir ortamın oluşmasını sağlayacağı iddiasıyla adeta kutsanan ve bu sayede de hızlı bir şekilde yayılan kitle çalışması, teknolojinin çalışma hayatına kattı̆̆ 1 yeni bir kavramdır ${ }^{7}$. Gerçekten de, isteyen herkesin bilgiye erişimini ve kişilerin birbirleriyle iletişim kurmasını oldukça kolaylaştırması bakımından temel demokratik hakların kitle çalışmasında mevcut olduğu ifade edilebilecektir. Ancak kâğıt üzerinde mevcut olan bu özgürlüklerin, uygulamada hiç de anlatıldığg şekilde hayat geçmediği görülmektedir.

Kitle çalışması, sanal bir platform üzerinden sanal ortamda yapılması gereken işleri ${ }^{8}$ arz ve talep eden "bağımsız çalışanların" buluşturulduğu, çoğunlukla eser sözleşmesi temelinde oluşturulan bir çalışma biçimidir'. Her ne kadar kitle çalışmasında iş sahibi ve çalışan arasındaki hukuki ilişkinin temelini eser sözleşmesi oluştursa da; kitle çalışmasının yalnızca eser sözleşmesinin değil, farklı sözleşmelerin de (iş sözleşmesi, vekâlet sözleşmesi, satım sözleşmesi gibi) özelliklerini taşıması, onun yeni ve kendine özgü bir sözleşme türü olarak nitelendirilmesinin önünü açmaktadır ${ }^{10}$. Kitle çalışması olarak adlandırılan tüm çalışma biçimlerinin "sui generis" sözleşmeler başlığı altında toplanması, bir nevi kolaycılık olacaktır ${ }^{11}$. Bu tür sözleşmelerin mevcut sözleşme türlerinin herhangi birisine dahil edilememesinin temel sebepleri araştırılmalıdır. Kitle çalışmasını öngören sözleşmelerde, çalışanların esasında iş sahibine veya platforma bir işçi kadar, hatta bazı hallerde daha fazla bağımlı olabildiği dikkate alınmalıdır. Sözleşmenin sui generis bir sözleşme olarak tanımlanması sebebiyle iş yasalarının sağlayacağı korumalardan faydalanılamayacağı göz önünde bulundurulmalı, hak ve çıkarların mümkün olduğunca çalışan ile iş sahibi veya platform arasında dengeli bir şekilde paylaştırılması gözetilmelidir.

\footnotetext{
${ }^{7}$ Debra Howcroft, Birgitta Bergvall-Kåreborn, “A Typology of Crowdwork Platforms”, Work, Employment and Society, 33/1 (2019), s.22.

${ }^{8}$ Kitle çalışmasını platform aracılığıyla çalışmadan ayıran en temel nokta, kitle çalışmasının konusunu oluşturan işlerin sanal ortamda gerçekleştirilmesidir. Oysaki platform aracıllğıyla çalışmada, gerçek hayatta yapılması gereken işler (su kaçağı tamiri, elektrik tesisatı döşenmesi vb.) konu edilmektedir. Bkz. Antonio Aloisi, "Commoditized Workers: Case Study Research on Labor Law Issues Arising from a Set of on-Demand/Gig Economy Platforms”. Comparative Labor Law \& Policy Journal, 37/3 (2016), s.661.

${ }^{9}$ Oliver Serfling, Crowdworking Monitor Nr. 1, Bundesministerium Für Arbeit und Soziales, 2018, s.6. Christine Gerber, Martin Krzywdzinski, "Brave New Digital Work? New Forms of Performance Control in Crowdwork", Work and Labor in the Digital Age, der. Steven P. Vallas, Anne Kovalainen, Bingley: Emerald, 2019, s.122.

${ }^{10}$ Serfling, Crowdworking Monitor Nr. 1, s.30.

${ }^{11}$ Jeremias Prassl, Martin Risak. "Uber, Taskrabbit, and Co.: Platforms as Employers-Rethinking the Legal Analysis of Crowdwork." Comparative Labor Law \& Policy Journal, 37/3 (2016), s.621.
} 
Kitle çalışmasında, işin mümkün olduğunca küçük parçalara bölünerek kısa zamanda ve düşük maliyetle yapılması/yaptırılması hedeflenmektedir. Örneğin; tercüme edilmek istenen bir kitabın bölümleri, hatta sayfaları kitle çalışması kapsamında platform aracılığıyla pek çok kişiye paylaştırılıp kişilerin üzerindeki iş yükünün azaltılması sağlanarak hem iş kısa sürede yaptırılabilmekte hem de yapılan işten dolayı kişilerin ortaya çıkabilecek hata, eksik ve yanlışlarının işin bütünü üzerindeki etkisi azaltılabilmektedir. Bu bakımdan kitle çalışmasını Taylorizmin yeni bir biçimi olarak değerlendiren görüşler giderek daha da yaygınlaşmaktadır ${ }^{12}$. Gerçekten de kitle çalışması sayesinde işin çok küçük parçalara bölünebilir hale gelmesi, fordist-taylorist üretim sisteminin sanal ortamda yeniden canlanmasını sağlamıştır. Ancak sanal fordist-taylorist sistem, aksayan yönleri törpülenen klasik halinden oldukça uzaktır. Zira klasik halinde işçiler üzerinde oluşturduğu olumsuz etkiler (yabancılaşma, motivasyon kaybı vb.) sanal versiyonunda aynen devam etmektedir. Üstelik bu sorunlara maruz kalan "bağımsız” çalışanların, bunları çözmek için tesis edilen iş yasalarından, hukuki statüleri itibarıyla faydalanmaları da mümkün olamamaktadır.

\section{Kitle Kaynak Kullanımı (Crowdsourcing)}

Kitle çalışması gibi, kitle kaynak kullanımı da teknolojik gelişmelerin neticesinde ortaya çıkan yeni bir kavramdır. Her iki kavramın da temelinde yatan mantık aynı olmakla birlikte, farklılaştıkları nokta, kitle kaynak kullanımında yapılan iş karşılığında ücret ödenmesinin zorunlu olmadığı durumların da gündeme gelebilmesidir $^{13}$. Kitle kaynak kullanımında temel esaslardan biri, "gönüllülük”tür. İnsanlar, iş sahibine veya platforma katkıda bulunmak amaciyla, emeklerini herhangi bir bedel beklemeden sunmaktadırlar. İş sahibinin veya platformun sunduğu hizmetin hedefi yardım veya gönüllülük faaliyeti olabildiği gibi, kâr elde etmek de olabilir. Zaten kitle kaynak kullanımı bakımından sorun oluşturan ve iş hukuku açısından incelenmesini gerektiren husus da bu noktada ortaya çıkmaktadır.

Kitle kaynak kullanımı uygulamalarına her geçen gün daha sık rastlanmaktadır. İnsanlar, takdir edilme ve küçük de olsa bir şeyleri başarma amaciyla herhangi bir ücret talep etmeksizin örneğin çektikleri fotoğrafları haber kanallarına gönderebilmekte, bir internet sitesine katkıda bulunabilmekte ya da platformlar aracılığıyla ilan edilen işlere gönüllü olarak katkı sunabilmektedirler. Cep telefonlarıyla çekilen görüntüler, yalnızca görüntüyü çeken kişinin adının haberde zikredilmesi karşılığında haber kanallarınca rahatlıkla kullanılabilmektedir.

Kitle kaynak kullanımının, kitle çalışmasındakine benzer bir şekilde, çalışma hayatında demokrasinin tesis edilmesi, bilimsel ve teknolojik gelişmeye katkı sunulması, verimliliğin arttırılması, insanların ortaklaşa iş yapabilme kabiliyetlerinin geliştirilmesi ve toplumda yardımlaşma duygularının gelişmesini sağlaması gibi amaçlara hizmet ettiği ve bu sebeple de desteklenmesinin gerektiği ifade edilmektedir $^{14}$. Kitle kaynak kullanımı uygulamalarına yalnızca gönüllülük esaslı çalışma-

\footnotetext{
${ }^{12}$ Aniket Kittur vd., "The Future of Crowd Work", Proceedings of the 2013 Conference on Computer Supported Cooperative Work (CSCW '13), New York: Association for Computing Machinery, 2013, s.24.

${ }^{13}$ Julian Schulte, Katharina D. Schlicher, Günter W. Maier, "Working Everywhere and Every Time? - Chances and Risks in Crowdworking and Crowdsourcing Work Design", Gruppe. Interaktion. Organisation. Zeitschrift für Angewandte Organisationspsychologie, 51 (2020), s.62.

${ }^{14}$ Wei Li, Wei-Tek Tsai, Wenjun Wu, "Crowdsourcing for Large-Scale Software Development", Crowdsourcing: Cloud-Based Software Development, der. Wei Li, Michael N. Huhns, Wei-Tek Tsai, Wenjun Wu, Springer,
} 
larda başvurulması halinde, ifade edilen amaçların bu çalışma biçiminin temel hedefleri olduğu rahatlıkla kabul edilebilirdi; fakat gittikçe yaygınlaşan bir biçimde kâr amacı güden şirketlerce de kullanılır hale gelmesi ${ }^{15}$, bu konuda şüphe oluşmasına yol açmaktadır. Kişilerin gönüllü olarak sundukları hizmetler, aldıkları reklamlarla bu hizmetler sayesinde kâr elde eden platformlarca kullanılmakta, fakat bu kârın elde edilmesi için hizmeti sunan kişiler ya kârdan herhangi bir pay alamamakta ya da çok düşük bir pay alabilmektedirler. Öyle ki, normalde sunduğu fotoğrafçılık hizmeti için cömert bir indirim yapmasına rağmen altıyüz dolardan daha düşük bir rakam belirlemesi mümkün olmayan bir kişinin artık çeşitli platformlarda sunulan "gönüllü" fotoğrafçılık hizmetleri sebebiyle, fotoğraf başına bir dolardan daha fazla gelir elde edebilmesi imkânsız hale gelmiştir ${ }^{16}$.

Sonuç olarak, kitle kaynak kullanımı uygulamalarının, her ne kadar temelinde yüce ideallerin bulunduğu iddia edilse de kullanılma biçimi göz önünde bulundurulduğunda pek de bu ideallere hizmet etmediği ortadadır. Bu sebeple, anlatılan ve gösterilmek istenenin arkasına bakabilmek ve çalışma hayatına ilişkin ortaya çıkan veya çıkması muhtemel olan sorunların çözümüne yönelik tedbirlerin alınması gerekmektedir.

\section{Esnek Ekonomi (Gig Economy)}

Sanal işyeri modeli üzerinde şekillenen kitle çalışması ve platform temelli çalışma kavramlarının temelini oluşturduğu "gig economy" kavramı, kelime manası itibarıyla birebir çevrildiğinde "iş ekonomisi" ifadesiyle tercüme edilmektedir. Kavramın oluşturulma amacı dikkate alındığında ise "esnek ekonomi" tercümesinin daha uygun olduğu görülmektedir.

Esnek ekonomi kavramı, çalışma hayatında yasaların düzenlemiş olduğu tüm sınırlamalardan kaçınma amacıyla ${ }^{17}$, sözleşme serbestisi ilkesini ve liberal ekonomi anlayışını esas alarak yeni bir çalışma düzeni oluşturmaktadır. Bu bakımdan, çalışanların herhangi bir koruma mekanizmasına sahip olmadıkları Sanayi Devrimi'nin ilk zamanlarında ortaya çıkan çalışma ortamıyla önemli benzerlikler taşımaktadır. Esnek ekonomideki temel motivasyon, mümkün olan en yüksek geliri herhangi bir sosyal yükümlülüğe (yıllık ücretli izin, kıdem tazminatı, iş güvencesi vb.) tabi olmadan elde etmek, bu sayede de kârı maksimize etmektir. Esnek ekonomi kavramını esnekleşme veya esnek işten ayıran en önemli husus, esnek ekonomide artık iş hukuku kapsamına giren bir işçi-işveren ilişkisinden bahsedilemiyor olmasıdır. Esnekleşme veya esnek iş, iş yasalarının sınırları çerçevesinde kalarak maliyetlerin mümkün olduğunca düşük gerçekleşebileceği çalışma ilişkilerinin oluşturulmasını hedeflemektedir. Dolayısıyla, işçi-işveren ilişkisinin varlığı ortadan kalkmamakta ve işçiler iş yasalarıyla sağlanan korumalardan faydalanabilmektedir. Oysaki esnek ekonomide artık işçi - işveren ilişkisinden ve dolayısıyla da İş Kanunu kapsamına giren bir ilişkiden bahsedilememektedir. Zira esnek ekonomide, işçi kavramı ve kanunlarda tanımlandığı şekliyle işçiler bulunmamaktadır.

\footnotetext{
2015, s.3.

${ }^{15}$ Enrique Estellés-Arolas, Raúl Navarro-Giner and Fernando González-Ladrón-de-Guevara, "Crowdsourcing Fundamentals: Definition and Typology", Advances in Crowdsourcing, der. Fernando J. Garrigos-Simon, Ignacio Gil-Pechuán, Sofia Estelles-Miguel, Springer, 2015, s.33-48.

${ }^{16}$ Jeff Howe, "The Rise of Crowdsourcing", Wired Magazine, 14.06, 2006, s.1.

${ }^{17}$ Valerio De Stefano, “The Rise of the Just-in-Time Workforce: On-Demand Work, Crowdwork, and Labor Protection in the Gig-Economy”, Comparative Labor Law \& Policy Journal, $37 / 3$ (2016), s.473.
} 
Esnek ekonomide, kitle çalışması ve platform çalışması gibi teknolojik gelişmeler sayesinde ortaya çıkan yeni çalışma şekilleriyle işçiler değil, "bağımsız" çalışanlar istihdam edilmektedir. "Bağımsız" çalışanlar, her ne kadar bir işçiye kıyasla ekonomik ve hiyerarşik bakımdan iş sahibine daha bağımlı olsalar da, iş sahibi ile aralarında kurulan hukuki ilişkinin temelini çoğunlukla eser sözleşmesinin oluşturması, onların bağımsız veya kendi hesabına çalışan olarak nitelendirilmelerine sebep olmaktadır ${ }^{18}$. Buna ilaveten, iş sahibinin herhangi bir işyeri tahsis etme ve istihdam ettiği kişileri bir işyerinde çalıştırma zorunluluğunun da teknolojik gelişmeler sayesinde ortadan kalkması, istihdam edilen kişilerin bağımlılık düzeylerinin tespit edilmesini zorlaştırmaktadır. "Bağımsız" çalışanlar istihdam ederek hem işçi çalıştırmaktan hem de işyeri açmak ve idame ettirmekten kaynaklanan sorumluluklardan ve maliyetlerden kaçınma ortamı oluşturan esnek ekonomik düzende çalışanların sosyal korumaya duydukları ihtiyaç, bir endişe kaynağı olarak görülmemektedir.

Esnek ekonomi kavramının, kitle çalışması, kitle kaynak kullanımı ve platform çalışması kavramlarını toparlayıcı nitelikte olması ve bu kavramların tüm özelliklerini içerisinde barındırması, onun söz konusu kavramların kendi içlerindeki sınırlamalara da tabi olmaması sonucunu doğurmaktadır. Dolayısıyla esnek ekonomi, hem sanal ortamda yapılan işleri hem de sanal platformlar aracılığıyla alınan, fiziksel olarak yapılan işleri de içermektedir ${ }^{19}$. Bu bakımdan esnek ekonomi, sanal dünyada oluşturulan, fakat gerçek dünyaya da etkileri olan bir kavram olarak nitelendirilebilecektir.

\section{Sanal İşyerlerinin Tercih Edilme Sebepleri}

\section{İşçiler Açısından}

\section{Rahat Bir Çalışma Ortamı Sağlaması}

İşyerinin sanallaşması, işin fiziksel olarak nerede yapıldığını da önemsiz hale getirmiştir. Özellikle büro işleri bakımından, işin yapılması için oluşturulan sanal ortama giriş yapıldığı veya erişilebildiği sürece işçinin fiziksel olarak nerede bulunduğu işin yapılmasında herhangi bir sorun oluşturmamaktadır. Zira artık işyerine uzaklık ve bu uzaklıktan dolayı işyerine gelememe, geç gelme vb. sorunların ortaya çıkması imkânsız hale gelmiştir.

İşin fiziksel olarak nerede yapıldığının önemli olmaması, işin yapılacağı yeri belirleme konusunda işçilere daha geniş bir takdir hakkı sunmaktadır. İşçiler, artık işyerine fiziken gitme zorunluluğu olmaksızın, işin yapılması için kullanılan sanal platforma erişebildikleri her yerde, örneğin; evinde, bir kafede, restoranda veya kendine uygun bulduğu herhangi bir yerde işini yapabilecektir. Dijitalleşme sayesinde, işçinin kendisini daha rahat hissedeceği, daha verimli olabileceğini düşündüğü bir ortamda çalışması artık mümkün hale gelmiştir. Ancak işçinin bu noktadaki takdir hakkının sınırsız olmadığını da belirtmek gerekir. Uzaktan Çalışma Yönetmeliği $\mathrm{i}^{20} \mathrm{~m}$. 5/2' de ifade edildiği üzere, yazılı olarak yapılan uzaktan çalışma sözleşmesinde işin nerede yapılacağının taraflarca belirlenmesi gerekmektedir. Dola-

\footnotetext{
${ }^{18}$ Gerber/ Krzywdzinski, “Brave New Digital Work”, s.122.

${ }^{19}$ Schulte vd., "Working Everywhere and Every Time”, s.60. De Stefano, “The Rise of the Just-in-Time Workforce", s.476-477.

${ }^{20}$ RG Tarih: 10 Mart 2021, Say1: 31419.
} 
yısıyla, işçinin çalışacağı yeri belirleme yetkisi bütünüyle kendisine ait değildir. Bununla birlikte, kanunda aksi yönde bir hüküm bulunmadığından, tarafların sözleşmede işin birden fazla yerde yapılabileceğini belirlemeleri mümkündür. İşçi yararına yorum ilkesi gereğince, işçinin talep etmesi halinde birden fazla yerde çalışabilmesi işçinin de lehine olacağından, kanun hükmünün tek bir yerde çalışılmasını öngörmediği şeklinde yorum yapılması yerinde olacaktır.

\section{Mesai Saatlerinin İstenildiği Gibi Ayarlanabilmesi}

Klasik bir işyerinde çalışma, belirli saatlerde gerçekleştirilir. Çalışmanın tam süreli, kısmi süreli, postalar halinde veya çağrı üzerine vb. şekillerde yapılması söz konusu olsa da, çalışma saatlerinin mutlaka belirlenmesi gerekmektedir. Bu saatler dışında çalışma yaptırılması halinde ise fazla çalışma veya fazla sürelerle çalışma ücretinin ödenmesi gerekecektir. Çalışma saatleri dışında işçinin çalıştırılmasının işveren bakımından doğuracağı tek maliyet, fazla çalışma ücreti değildir. İşçinin işyerinde geçirdiği her dakika, işveren için işyerinden doğan maliyetlerin de artması anlamına gelmektedir. Bu sebeple işveren, tüm işçilerini çalışma saatleri içerisinde çalıştırmak ve çalışma saatleri dişında da işyerini maliyet oluşturmayacak veya asgari ölçüde maliyet oluşturacak şekilde yönetmeye/işletmeye çalışmaktadır. Ancak sanal işyerleri bakımından bu tür bir kısıttan söz etmek mümkün değildir.

Sanal işyerleri -belirli saatlerde yapılması gereken işler haricinde- işçilerin günün herhangi bir saatinde çalışabilmelerine imkân sağlamaktadır ${ }^{21}$. Zira ortada fiziksel bir işyeri bulunmadığından işçilerin çalışma saatlerinin farklılaşması, işyerinden temelli ek bir maliyet de doğurmamaktadır. İşçiler çalışma saatlerini diledikleri gibi ayarlayabilmekte, örneğin gece vakti de çalışabilmektedirler. Ancak tabii ki işçilerin çalışma saatlerini belirleme bakımından da birtakım sınırlamalar mevcuttur. İşçi, sözleşmede belirlenen (günlük veya haftalık) çalışma süresinin altında çalışma hakkına sahip değildir. İşçi yalnızca, belirlenen çalışma süresini dilediği gibi bölümlendirme ve gün içerisinde dilediği vakitlerde kullanma hakkına sahip olabilmektedir. Ancak bu hakkın da her sanal işyeri esaslı çalışmada var olduğundan bahsedilemeyecektir. Şayet iş sözleşmesinde, günün belirli saatlerinde çalışılacağ öngörülmüşse veya bu bir çalışma şartı olarak belirlenmişse, iş sanal ortamda yapılsa dahi işçinin bu saatlere uyması gerekmektedir.

\section{İsyerindeki Eşitsizliklerin Giderilmesi}

Bir işyerinde veya çalışma ortamında, çalışan kişilerin tek tip olmaları, aynı bilgi kültür seviyesine, aynı değer yargılarına, aynı beceri seviyesine sahip olmaları, aynı millete mensup olmaları ya da aynı cinsiyetten olmaları mümkün değildir. Böylesi bir ortam, ancak herhangi bir kimliği veya bağımsız düşünme yeteneği olmayan robotların kullanıldığı bir işyerinde söz konusu olabilecektir. Bu sebeple, kişilerin insan olmaktan kaynaklanan bazı farklılıkları olabilmektedir. Ancak mevcut çalışma hayatı ve ekonomik düzen kâr maksimizasyonu esasına dayandığından, sosyal koruma, eşitsizliklerin giderilmesi gibi kaygılar geri plana itilebilmektedir. Kadınların çalışma hayatına katılımlarının düşük seviyede gerçekleşmesi, engelliliğin ve "yabancı" olmanın iş bulmada yaşattığı zorluklar bu bakımdan çalışma hayatında sıklıkla görülen sorunlar arasında yer almaktadır.

${ }^{21}$ Serfling, Crowdworking Monitor Nr. 1, s.28 
Fiziksel bir işyerindeki sınırlılıkların olmadığı, örneğin kadınların hem aile yaşantılarını neredeyse hiçbir değişikliğe uğramadan sürdürebildikleri hem de kariyerlerinde ilerleme imkânı bulabildikleri, engelli vatandaşların engellerinden dolayı herhangi bir sorun yaşamadan işlerini yapabildikleri sanal işyerlerinde, çalışma hayatında mevcut olan eşitliğe aykırı bazı uygulamaların ortadan kaldırılması mümkün hale gelmektedir ${ }^{22}$. Ancak tabii ki teoride mümkün olan bir durumun uygulamada her zaman teoriye uygun bir şekilde gerçekleşmesi söz konusu olmamaktadır. Nitekim sanal işyeri uygulamalarının ve organizasyonlarının, kadınlar ve erkekler arasında hâlihâzırda var olan eşitsizlikleri göz ardı ederek oluşturulması neticesinde, cinsiyet eşitsizliğinin giderek daha da arttığı görülmektedir ${ }^{23}$.

\section{İşverenler Açısından}

\section{Işçi İstihdam Etmekten ve Işyerinden Kaynaklanan Maliyetlerin Düşmesi}

Dijitalleşme ve teknolojik gelişmelerin insan gücüne olan ihtiyacı giderek ortadan kaldırması neticesinde, artan işgücü arzını karşılayacak iş imkânları azalmaktadır. Zira insanların yerine yapay zekâ sahibi robotlar üretim süreçlerine dâhil edilmektedir. Bu durum da teknolojik işsizliğin muhatabı olmaktan bir şekilde kurtulmuş işçileri daha da düşük ücretlerle çalışmaya zorlamakta ve işverenlerin zaten var olan avantajlı pozisyonlarını daha da avantajlı hale getirmektedir. Ancak düşük ücret, dijitalleşmenin etkisiyle çoğu zaman insana yaraşır bir yaşam sürdürmeyi dahi temin edemeyecek seviyede gerçekleşmektedir. 1 dolara fotoğraf satın alınan bir ortamda profesyonel fotoğrafçılık mesleğinin varlığını sürdürebilmesi imkânsızdir.

Ayrıca artık vasıflı elemana duyulan ihtiyaç da eskisi kadar yüksek değildir. Zira çok düşük ücretler karşılığında platformlara hizmet sunan kişiler ve bunların sunduğu hizmetler o kadar fazladır ki, bunların arasından işverenin işine yarayacak bir işçiyi, kullanabileceği bir ürünü veya hizmeti bulması hiç de zor olmamaktadır. Dolayısıyla, kısıtlı bir insan kaynağının verimini arttırmak veya vasıf ve verim seviyesi yüksek işçileri istihdam etmek için katlanılan yüksek maliyetler, aynı kalitede ürün veya hizmetlerin ücretsiz ya da çok düşük ücretle ve gönüllü olarak verilmesi sayesinde ortadan kalkmaktadır. Bunun neticesinde de vasıflı işçilerin işverenlere karşı sahip oldukları avantajlı konum, kaybolmaktadır ${ }^{24}$.

İş ve işyeri organizasyonu içerisinde önemli bir yeri olan insan kaynakları birimlerine duyulan ihtiyaç da artık ortadan kalkmaktadır ${ }^{25}$. İşçi yerine "bağımsız" çalışanların istihdam edilmesi, işçileri işe alma-işten çıarma ve iş süreçleri içerisinde işgücü planlaması yapmakla yükümlü insan kaynakları birimlerinin varlığını da gereksizleştirmektedir. Neticede, işveren hem işçilere ödediği ücret ve diğer yasal yükümlülüklerinden kurtulmakta hem de işyeri organizasyonunu daha da küçülterek işyerinden kaynaklanan maliyetleri azaltabilmektedir ${ }^{26}$.

\footnotetext{
${ }^{22}$ Heeks, "Decent Work", s.9. Norat Roig-Tierno, Cristina Blasco-Carreras, Alicia Mas-Tur and Belén RibeiroNavarrete, "Using Crowdsourcing to Overcome Barriers to Women Entrepreneurship", Advances in Crowdsourcing, der. Fernando J. Garrigos-Simon, Ignacio Gil-Pechuán, Sofia Estelles-Miguel, Springer, 2015, s.121-125.

${ }^{23}$ Michelle A. Travis, "Equality in the Virtual Workplace", Berkeley Journal of Employment and Labor Law, 24/ 2 (2003), s.285.

${ }^{24}$ Prassl/Risak. "Uber, Taskrabbit, and Co.", s.625.

${ }^{25}$ De Stefano, "The Rise of the Just-in-Time Workforce", s.478.

${ }^{26}$ Cascio, "Managing a Virtual Workplace", s.81.
} 


\section{Iş̧̧iler Üzerindeki Kontrolün Artması}

İşverenin işçi üzerindeki kontrolü, iş sözleşmesinde bağımlılık ilişkisi tespiti sürecinde varlığı aranan ilk ve en önemli husustur. Nitekim işçi ve işveren arasındaki hiyerarşinin varlığını, işverenin kurduğu iş organizasyonu içerisinde işverenin işle ilgili emir ve talimatlarını uygulamakla yükümlü kişilerin varlığına bağlayan kontrol testi; işveren tarafından kurulan işyerinde, onun belirlediği zamanlarda ve onun belirlediği yöntemlerle çalışılmasını bağımlılık ilişkisinin varlığı bakımından zorunlu görmektedir. Buradan yola çıkıldığında, kişilerin istedikleri yerde, istedikleri zamanda ve istedikleri şekilde çalışabilmelerini sağlayan kitle çalışması modellerinde işverenin çalışanları üzerindeki kontrolünün arttığından bahsetmek, ilk bakışta yanlış bir iddia gibi durmaktadır. Ancak işçilerin işyerinde bulundukları sınırlı bir süre zarfında işverenin emir ve talimatlarına uymakla yükümlü oldukları ve bu süre haricinde yalnızca sadakat yükümlülügüne aykırılık hallerinde sorumlu tutulabilecekleri klasik çalışma modelindeki kontrolün derecesi ile haftanın her günü ve günün her saati işverenden emir ve talimat almaya hazır bulunmak zorunda oldukları ${ }^{27}$ modeldeki kontrol derecesi kıyas kabul etmeyecek düzeyde farklidir.

Dijital platformlar, tüm bilgilerin herkese açık olduğu bir ortam olarak gösterilmekte ve bu sayede ideal iş piyasasının şartlarını oluşturduğu iddia edilmekteyse de aslında bu bir yanılsamadan ibarettir. Zira ideal bir iş piyasasında, iş değiştirmek isteyen bir işçinin sahip olduğu bilgi, tecrübe seviyesi ve bunun üzerine inşa edilen işveren değerlendirmeleri de aynı veya benzer nitelikteki işlere geçmek istediğinde dikkate alınmakta, o kişiyi istihdam eden işveren ücreti veya çalışacağ pozisyonu belirlerken bunları göz önünde bulundurmaktadır. Ancak dijital platformların birinde elde edilen bilgi, tecrübe, işveren veya müşteri takdir ve tavsiyeleri, bir diğer platforma taşınamamaktadır. Bu da, özellikle belirli bir çalışma tecrübesine ve kıdeme sahip olan kişilerin platformlar arasında tercih yapabilmelerine engel olmakta, kişileri platformların "köle"si haline getirmektedir ${ }^{28}$.

Dijital platformlarda yapılan işlerin veya belirlenen görevlerin niteliği de kişilerin işverene olan bağımlılıklarını arttırmakta, işverene daha sağlam ve geniş bir kontrol imkânı vermektedir. Dijital platformlar aracılığıyla ilan edilen işler, genellikle asıl yapılması gereken işin çok küçük birimlerini oluşturmaktadır ${ }^{29}$. Örneğin, bir bilgisayar oyunu yazılımında her bir karakterin tasarımı farklı bir kişiye verilmekte, böylece olası hatalar ve bu hatalardan/eksikliklerden/gecikmelerden doğan zararlar en aza indirilmektedir. İşveren, her bir karakterin nasıl tasarlanması gerektiği konusunda ayrıntılı talimatlar verebilmekte, bu talimatlara uyma konusunda sorunlar yaşanması durumunda işi kolaylıkla başka bir kişiye aynı veya daha düşük maliyetle yaptırabilmektedir.

\section{İsin Iş̧̧i Istihdam Etmeksizin de Gördürülebilmesi}

Platformlar aracılığıyla çalıştırılan veya kendisinden hizmet alınan kişiler, kendilerini işçi olarak görmemekte ve bu yönde bir talepleri de bulunmamaktadır. Dolayısıyla işverenler, ne hukuki ne de ekonomik açıdan aralarında bağımlılık ilişkisi

\footnotetext{
${ }^{27}$ Heeks, "Decent Work", s.13. De Stefano, "The Rise of the Just-in-Time Workforce”, s.480.

${ }^{28}$ De Stefano, "The Rise of the Just-in-Time Workforce", s.14.

${ }^{29}$ De Stefano, "The Rise of the Just-in-Time Workforce", s.474.
} 
bulunmayan "bağımsız" çalışanlar aracılığıyla ihtiyaç duydukları ürün ve hizmetleri elde edebilmektedirler. Buna karşın; çalışma şartları platform tarafından en ince ayrıntısına kadar belirlenebilmekte ve bunlara uyulmaması halinde "bağımsız" çalışanların platforma üyelikleri sonlandırılmakta ve platform aracılığıyla iş alma imkânları da ortadan kalkmaktadır. Ayrıca bu kişilerin ücretleri, kendisi için hizmet verdikleri kişi/ler tarafından doğrudan kendilerine ödenmemektedir. Hizmet karşılığı ücret öncelikle platforma ödenmekte, platform kendi payını aldıktan sonra ücret, platform tarafından, hizmeti veren kişiye ödenmektedir. Dolayısıyla kişiler, verdikleri hizmet karşılığında elde edecekleri ücret bakımından platforma bağımlıdırlar ${ }^{30}$.

İşini "bağımsız" çalışanlar eliyle yaptıran işverenler, işçi istihdam etmekten doğan sorumlulukların hiçbiriyle yükümlü tutulamamaktadır. Her ne kadar işverenler için bu durum çok büyük bir fayda sağlamaktaysa da, sosyal korumaya ihtiyaç duyan "bağımsız" çalışanlar açısından o denli kayba sebep olmaktadır. İhtiyaç duyduğu sosyal korumaya erişemeyen çalışanların toplumda ve çalışma ortamında oluşturdukları huzursuzluğun ve toplumun tümü üzerindeki etkilerin gözlemlenebilmesi bakımından Sanayi Devrimi sonrası yaşanan gelişmeleri incelemek yeterli olacaktır.

\section{İşyerinin Sanallaşmasının İş Hukuku Açısından Doğurduğu Bazı Sorunlar}

\section{Asgari Ücret Düzenlemelerinin Uygulanamaz Hale Gelmesi}

İşyerinin sanallaşması neticesinde, işvereni "işçi” istihdam etmeye zorlayan ve çalışan kişilerin işçi olarak nitelendirilmesinde dikkate alınan "işyeri” unsuru, önemini kaybetmektedir. İnternet ve sanal platformlar sayesinde işverenin istediği her an uygun bir ücret karşılığında kendilerine herhangi bir işyeri göstermeden işini yaptırabileceği kişileri bulması kolaylaşmakta, bu da işçi ve işveren arasında birbirlerine duydukları ihtiyaç temelinde gündeme gelen sadakat yükümlülügünü de bertaraf etmektedir. Zira özellikle işçilerin alternatiflerinin kolaylıkla bulunabilmesi, işin fiziksel bir mekânda yapılmaması ve bu sebeple işyeri olarak nitelendirilecek bir yerin de bulunmaması, maliyetlerden kaçınmak isteyen işveren bakımından, istihdam edilen kişilerin "işçi” kategorisi altında istihdam edilme gerekliliğini yok etmektedir. Sanal işyerlerinde, işverenleri "işçi” istihdam etmeye zorlayan pek çok yasal düzenleme, uygulama imkânı bulamamaktadır. İş sözleşmesinin bağımlılık unsurunda yaşanan zayıflama da dikkate alındığında, kimin işçi/bağımlı çalışan olduğunun tam bir kesinlikte tespit edilmesi mümkün olmadığından, işverenler artık "işçi" istihdam etmek yerine, kendilerine daha az maliyet doğuran "bağımsız" çalışanlar istihdam etme yolunu tercih etmektedirler.

Aslında hiç de bağımsız olmayan, hatta işverene normal bir işçiden ekonomik bakımdan daha bağımlı olan "bağımsız" çalışanların istihdam edilmesi, işverenlerin genel giderler arasında önemli bir kalem olarak değerlendirdikleri işçi ücretlerinin olabildiğince düşük bir seviyede belirlenmesinin önünü açmaktadır ${ }^{31}$. Zira bağımsız çalışanlar bakımından hala pek çok ülkede ücretin asgari bir sınırı bulunmamaktadır. İşgücüne ulaşma bakımından internetin işverenler lehine oluşturduğu

${ }^{30}$ Prassl/Risak. "Uber, Taskrabbit, and Co.", s.624.

${ }^{31}$ Guy Davidov, “Indirect Employment: Should Lead Companies Be Liable?”, Comparative Labor Law \& Policy Journal, 37/5 (2015), s.13. 
“ideal” ortam ${ }^{32}$, iş arayanların kendilerini daha cazip kılabilmek için ücretleri aşağıya çekmelerine ve bir nevi “yoklukta yarışmalarına” yol açmaktadır ${ }^{33}$.

Asgari ücret seviyesi bir yana, çoğu zaman yoksulluk seviyesinde dahi oluşmayan ücretler, çalışanların güvencesiz, iş yasalarının sağladığı herhangi bir korumadan faydalanma imkânına kavuşamayacakları işleri tercih etmelerini zorunlu kılmaktadır. Sonuç olarak, yasalarda asgari ücret düzenlemeleri mevcut olsa da bu düzenlemeler, ihtiyacı olan kişileri korumaktan uzak kalmaktadır.

\section{İş Sağlığı ve Güvenliği Hükümlerinin Uygulanamaz Hale Gelmesi}

İşyeri, iş sağllğı ve güvenliği tedbirlerinin alınabilmesi ve kanun hükümlerinin gerektiği şekilde uygulanabilmesi bakımından bir temel niteliğini taşımaktadır. Zira ortaya çıkacak risklerin ve tehlikelerin neler olduğu, her işyerinin kendi özelliklerine göre belirlenmektedir. Tabii ki işyerlerinde asgari düzeyde alınması gereken ve tüm işyerleri için ortak olan önlemler bulunmaktadır, ancak yapılan işin tehlike derecesine ve işyerinin bulunduğu yere, taşıdığı özelliklere göre ilave tedbirlerin alınması da gerekebilmektedir.

Esnek çalışma, uzaklaştırma stratejileri ve özellikle de dijitalleşme neticesinde işyerinin sabit ve belirli olma niteliğini kaybetmesi, iş sağlı̆̆ ve güvenliğine ilişkin yasal düzenlemelerin de uygulanabilirliğini zorlaştırmaktadır. İş sağlı̆̆1 ve güvenliğine ilişkin yasal düzenlemeler, risklerin ve tehlikelerin net olarak tespit edilememesi sebebiyle işyerinde ortaya çıkabilecek kazaları ve zararları önleme amacını gerçekleştirmek için artık kullanılamamaktadır. İşverenin işyerinde ortaya çıkan zararlardan sorumlu olması ve buna ilişkin tazminat yükümlülügünün bulunduğu, bu sebeple de işyeri sabit olmasa dahi iş sağlığı ve güvenliğine ilişkin düzenlemelerin uygulanabilirliğini muhafaza ettiği iddiası maalesef ki yerinde olmayacaktır. Zira her ne kadar işverenin yasal olarak bir yükümlülüğü bulunsa da, kendi müdahale alanı dışında olan ve sabit olmayan yerlerdeki risklere ve tedbirlere karşı önlem alması kendisinden beklenemeyeceğinden, ortaya çıkan zararlardan da işvereni tazminat borcu altına sokmak hakkaniyete uygun olmayacaktır.

Sabit bir işyerinin mevcut olmaması, elbette iş sağlığı ve güvenliği düzenlemelerinin uygulanması bakımından birtakım sorunları gündeme getirmektedir. Bununla birlikte, iş sağlığı ve güvenliği bakımından gerekli tedbirlerin alınmadığı işyerlerinde oluşacak tehlikelere maruz kalınmasını engellemesi açısından işçilerin lehine bir durum da oluşturabilmektedir. Zira bu sayede işçi, sağlığından ve güvenliğinden endişe etmeyeceği bir yerde çalışma imkânına kavuşacak ve aynı zamanda yaptığı iş karşılığında ücrete de hak kazanacaktır. Konuya pragmatik yaklaşıldığında, platformlar aracılığıyla çalışmanın bu tür bir faydasından bahsetmek mümkün olsa da hukuki açıdan ele alındığında bu durumun hukuka ve kanun koyucunun amacına uygun olmadığını ifade etmek gerekmektedir.

\section{Sendikal Örgütlenmenin Zorlaşması}

Bir işyerinde veya işletmede sendikal örgütlenmenin gündeme gelebilmesi için, öncelikle işçilerin ortak karar alabilecekleri, yani birbirleriyle temasa geçebilecekleri

\footnotetext{
${ }^{32}$ Cristiano Codagnone, Fabienne Abadie, Federico Biagi, The Future of Work in the 'Sharing Economy', Seville: EC Joint Research Centre, 2016, s.6.

${ }^{33}$ Ben Z. Steinberger, "Redefining Employee in the Gig Economy: Shielding Workers from the Uber Model", Fordham Journal of Corporate and Financial Law, 23/2 (2018), s.594.
} 
bir ortamın bulunması gereklidir. Bu ortam, işçilere ortak sorunlarını ve bunların çözümlerini birbirleriyle paylaşma imkânı sağlayacağından, kolektif hareket etme yönünde karar alınmasına da zemin hazırlayacaktır ${ }^{34}$. Dijitalleşmeyle birlikte, iletişimin daha da kolaylaştığı ve aynı işyerinde çalışıyor olmasalar dahi işçilerin her an için birbirleriyle temasta olabilecekleri, bu sayede de sendikal örgütlenmenin ve sendikal örgütlenmenin en temel motivasyonlarından biri olan toplu sözleşme yapabilmenin önünde öncekine nazaran daha az engel olduğu iddia edilebilecektir. İki temel gerçek göz önünde bulundurulduğunda, söz konusu iddianın mevcut durumla bağdaşmadığı açık bir şekilde ortaya konulacaktır.

İlk olarak, dijitalleşmenin işyeri ve iş yapma şekilleri üzerinde oluşturduğu etkiler, işverenleri işçi istihdam etmek yerine "bağımsız" çalışanlar istihdam etmeye yönelttiğinden ${ }^{35}$ ve bu kişilerin toplu sözleşme yapma hakları bulunmadığından, işverenlerin karşısında en temel haklar arasında yer alan asgari ücret, dinlenme vb. haklarını dahi bir "hak" olarak kabul ettirmeleri mümkün olmamaktadır. Söz konusu "bağımsız" çalışanlar işveren sıfatını haiz olmaları halinde sendikalara üye olabilecek ve dolayısıyla da toplu sözleşme yapma hakkına sahip olabileceklerdir. Bununla birlikte, kuracakları veya üye olacakları sendikalar aracılığıyla kendisine ekonomik olarak bağımlı oldukları ve kendisinden hak talep edecekleri işverenlerle aynı hukuki kategoride olmaları, bağımlı oldukları kişilerden talepte bulunmalarını engellemektedir. İşçi ve işveren arasındaki anlaşmazlıkları düzenlemeyi temel esas olarak alan toplu sözleşme ve sendikalaşmaya ilişkin yasal düzenlemeler de dikkate alındığında, bir işveren sendikasının, üyesi olan veya olmayan işverene karşı herhangi bir hak talep etme imkânının bulunmadığı ortadadır. Dolayısıyla, kendilerine ait işyerleri olan ve işverenin kurduğu işyerinde çalışmayan "bağımsız" çalışanlar toplu sözleşmelerle hak talebinde bulunamamaktadırlar. Oysaki aslında işçilerle kıyaslandığında sosyal korumaya daha çok ihtiyaç duyan bu sözde "bağımsız" çalışanların da sendikalara üye olabilmeleri veya en azından toplu sözleşme yapma hakkına sahip olmaları sosyal devlet ilkesine ve iş hukukunun amacına daha uygun düşecektir ${ }^{36}$. Her ne kadar tüzel kişilik perdesinin aralanması ve birlikte istihdam kavramlarıyla görünürdeki hukuki ilişkinin temelinde yatan asıl hukuki ilişkinin belirlenmesinin mümkün olduğu dile getirilse de, uygulamada sorunların devam ettiği görülmektedir.

İkinci olarak da, dijitalleşmenin ve işyerinin "sanallaşmasının" işverene iş organizasyonu bakımından sağladığ 1 avantajlı konumun sendikal örgütlenme üzerindeki etkisinden bahsetmek gerekmektedir. Fiziksel varlığ bulunan bir işyerinde işçilerin birbirleriyle temasa geçmelerini ve etkileşimde bulunmalarını engellemek mümkün değildir. Zira birbirlerini arada herhangi bir vasıta olmadan görebilmektedirler. Dolayısıyla, sendikal örgütlenmenin öncülü olan iletişim süreci, alışılageldik bir işyerinde rahatlıkla gerçekleştirilebilecektir. Sanal ortamlarda ise, işçilerin birbirleriyle doğrudan temasa geçmeleri mümkün olmamaktadır. Bu durum, işverene iş organizasyonunu işçilerin birbirleriyle mümkün olduğunca az iletişime geçebilecekleri şekilde tasarlama bakımından önemli bir fırsat sunmaktadır. Örneğin, işyerinde kimlerin çalıştığına dair işçileri bilgilendirme zorunluluğunun bulunmaması sebebiyle, işçiler yalnızca kendi bulundukları birimdeki ve işin yapıl-

\footnotetext{
${ }^{34}$ Prassl/Risak. "Uber, Taskrabbit, and Co.", s.628.

${ }^{35}$ Davidov, "Indirect Employment", s.6.

${ }^{36}$ Sayım Yorğun, Ekonomik Politikalar ve Endüstri İlişkilerinin Geleceği, İstanbul: Beta Basım, 2019, s.168.
} 
ması için zorunlu olarak temas kurdukları diğer işçilerle iletişim kurabilmektedirler. Kaldı ki bu iletişim de sınırlı bir çerçevede kalmakta, işçilerin iş haricinde ortak bir anlayış oluşturmalarına, birbirlerini tanımalarına imkân vermemektedir ${ }^{37}$. Sonuç olarak, sanal işyerlerinde sendikalaşmadan ve toplu pazarlık süreçlerini hayata geçirmekten bahsedilememektedir. Özellikle 80'li yıllardan sonra tüm dünyada dijitalleşmeyle birlikte sendikalaşma oranlarının hızla düşme eğilimi, bu durumu açıkça ortaya koymaktadır.

Teknolojik gelişmişlik indeksinin ilke beş sırasında yer alan İzlanda, Güney Kore, İsviçre, Danimarka ve Birleşik Krallık'taki sendika yoğunluklarına bakıldığında, dijitalleşmeye paralel olarak bu oranların düşüş gösterdiği tespit edilmektedir. Bu ülkelerde 2000 yılında sendika yoğunlukları sırasıyla; İzlanda'da \%89.4, Güney Kore'de \%11.4, İsviçre'de \%20.2, Danimarka'da \%74.5 ve Birleşik Krallık'ta \%29.7 olarak gerçekleşmiştir. Ancak 2017 ve 2018 yılı verilerine bakıldığında, İzlanda hariç diğer dört ülkede sendika yoğunluklarının önemli düşüşler yaşadığı görülmektedir. Buna göre 2017 yılında sendika yoğunluğu Güney Kore'de \% 10,4, İsviçre'de \%14.9 olarak gerçekleşmiştir ${ }^{38}$. İzlanda, Danimarka ve Birleşik Krallık’taki sendika yoğunlukları ise 2018 yılında sırasıyla; \%91.8, \%66.5 ve \%23.4 olarak gerçekleşmiştir. Bu ülkelerin ortalama sendika yoğunluklarının yıllar içerisindeki değişimine bakıldığında ise, eğilimin aşağı yönlü olduğu görülmektedir.

Grafik 1. Teknolojik Gelişmişlik Endeksinin İlk Beş Sırasında Yer Alan Ülkelerin Sendika Yoğunluğu Ortalaması (A ğırlıklı Olmayan)

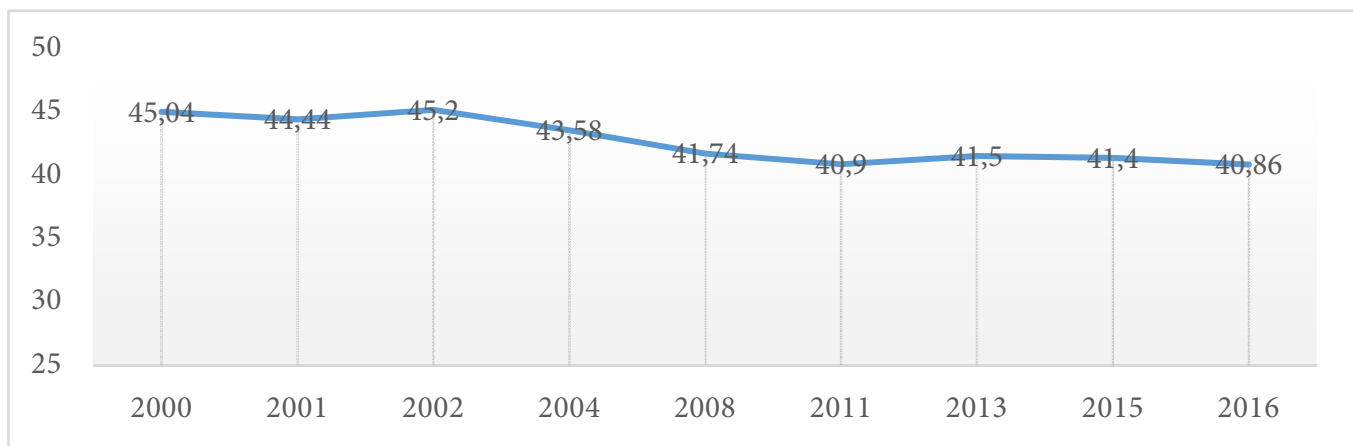

Kaynak: https://stats.oecd.org/Index.aspx?DataSetCode=TUD, (Çevrimiçi), 02.03.2021.

Tabii ki dijitalleşmeyi sendikalaşma eğiliminin azalmasındaki tek etken olarak görmek mümkün değildir. Yapısal, siyasal, sosyo-kültürel ve yasal pek çok unsurun sendikalaşma üzerinde etkilerde bulunduğu görülmektedir. Buna karşın, dijitalleşmenin sendikalaşma üzerindeki etkisini de görmezden gelmek mümkün değildir. Dijitalleşmenin söz konusu unsurların bir sonucu olmanın yanı sıra, onların etkilerini daha pekiştiren, hızlandıran bir etki gösterdiğini ifade etmek mümkündür.

\section{Sonuç}

Dijitalleşmenin işyeri kavramı ve bu kavram temelinde oluşturulan iş yasaları üzerinde oluşturduğu etki, işçilerin en temel haklarında aşınmaya yol açmaktadır. Elbette ki teknolojik gelişmelerin önünde durmak mümkün ve doğru değildir; fakat bu gelişmeler çalışma hayatının tarafları arasındaki dengeyi sağlayacak şekilde

\footnotetext{
${ }^{37}$ Howcroft/ Bergvall-Kåreborn, “A Typology of Crowdwork Platforms”, s.26.

${ }^{38} \mathrm{Bu}$ ülkeler 2018 yılında veri bildirmediklerinden dolayı, en son bildirimde bulundukları yıl olan 2017’ye ait oranlar verilmiştir.
} 
yönlendirilmelidir. Her ne kadar teknolojik gelişmişlik seviyesi bakımından günümüzün, Sanayi Devrimi'nin ortaya çıktığı dönemden büyük farklılıkları bulunsa da, çalışanlar üzerindeki etkileri bakımından her iki dönem birbiriyle önemli ölçüde benzeşmektedir. O dönemde iş hukukunun ayrı bir hukuk dalı olarak tesis edilmesini gerektiren gelişmeler, bu dönemde ise iş hukukunun yenilenmesini ve yeni kavramların geliştirilmesini gerektirmektedir.

İşverenlerin işçi yerine görünürde bağımsız, ancak esasında bir işçiye göre ekonomik ve hiyerarşik açıdan çok daha bağımlı olan çalışanları istihdam etme eğilimleri, zaten işverene karşı zayıf olan işçilerin ve genel olarak çalışanların, daha da zayıflamalarına sebep olmaktadır. Asgari ücret, sendikal haklar, iş sağlığı ve güvenliğinin sağlanması gibi temel haklara sahip olmayan bir çalışan grubunun ne derece savunmasız ve korunmaya muhtaç durumda olduğu ortadadır. İşyerinin sanallaşması neticesinde ortaya çıkan birtakım imkânsızlıklardan dolayı işverenin iş sağlı̆̆ 1 ve güvenliği gibi temel işçi haklarından sorumsuz olması ya da sorumluluğunun sınırlandırılması gerektiğini ileri sürmek, kolaycılık olacaktır. Sorun, mevcut düşünme kalıplarının ve kavramların dışına çıkılarak değerlendirilmeli, korunması gerekenin kavramlar veya mevcut hukuki düzenlemeler değil, hakkını savunma ve talep etme bakımından dezavantajlı kişiler oldukları dikkate alınmalıdır.

\section{Kaynakça}

Aloisi, Antonio. "Commoditized Workers: Case Study Research on Labor Law Issues Arising from a Set of on-Demand/Gig Economy Platforms". Comparative Labor Law \& Policy Journal. 37/3 (2016): 653-690.

Cascio, Wayne F. "Managing a Virtual Workplace". Academy of Management Executive. 14/3 (2000): 81-90.

Codagnone, Cristiano, Fabienne Abadie ve Federico Biagi, The Future of Work in the 'Sharing Economy'. Sevilya: EC Joint Research Centre, 2016.

Davidov, Guy. "Indirect Employment: Should Lead Companies Be Liable?". Comparative Labor Law \& Policy Journal. 37/5 (2015): 5-36.

De Stefano, Valerio. "The Rise of the Just-in-Time Workforce: On-Demand Work, Crowdwork, and Labor Protection in the Gig-Economy". Comparative Labor Law \& Policy Journal. 37/3 (2016): 471-504.

Degryse, Christophe. Digitalisation of the Economy and its Impact on Labour Markets. Brüksel: European Trade Union Institute, 2016.

Estellés-Arolas, Enrique, Raúl Navarro-Giner ve Fernando González-Ladrón-deGuevara. "Crowdsourcing Fundamentals: Definition and Typology". Advances in Crowdsourcing. Der. Fernando J. Garrigos-Simon, Ignacio GilPechuán, Sofia Estelles-Miguel. Springer, 2015: 33-48.

Gerber, Christine ve Martin Krzywdzinski. "Brave New Digital Work? New Forms of Performance Control in Crowdwork". Work and Labor in the Digital Age. Der. Steven P. Vallas, Anne Kovalainen. Bingley: Emerald. 2019: 121-143.

Hamblin, Heather. “Employees' Perspectives on One Dimension of Labour Flexibility: Working At A Distance”. Work, Employment \& Society. 9/3 (1995): 473-498.

Heeks, Richard. Decent Work and the Digital Gig Economy: A Developing Country Perspective on Employment Impacts and Standards in Online Outsourcing, Crowdwork, etc. Manchester: Centre for Development Informatics Global 
Development Institute, 2017.

Howcroft, Debra ve Birgitta Bergvall-Kåreborn, “A Typology of Crowdwork Platforms". Work, Employment and Society. 33/1 (2019): 21-38.

Jeff Howe, "The Rise of Crowdsourcing”, Wired Magazine. 14.06 (2006): 1-5.

Kittur, Aniket, Jeffrey V. Nickerson, Michael Bernstein, Elizabeth Gerber, Aaron Shaw, John Zimmerman, Matt Lease ve John Horton. "The Future of Crowd Work". Proceedings of the 2013 Conference on Computer Supported Cooperative Work (CSCW '13). New York: Association for Computing Machinery, 2013, 1301-1318.

$\mathrm{Li}$, Wei, Wei-Tek Tsai ve Wenjun Wu. "Crowdsourcing for Large-Scale Software Development". Crowdsourcing: Cloud-Based Software Development. Der. Wei Li, Michael N. Huhns, Wei-Tek Tsai, Wenjun Wu, Springer, 2015: 3-24.

Prassl, Jeremias ve Martin Risak. "Uber, Taskrabbit, and Co.: Platforms as Employers - Rethinking the Legal Analysis of Crowdwork". Comparative Labor Law \& Policy Journal. $37 / 3$ (2016): 619-652.

Roig-Tierno, Norat, Cristina Blasco-Carreras, Alicia Mas-Tur ve Belén RibeiroNavarrete. "Using Crowdsourcing to Overcome Barriers to Women Entrepreneurship". Advances in Crowdsourcing. Der. Fernando J. GarrigosSimon, Ignacio Gil-Pechuán, Sofia Estelles-Miguel. Springer, 2015: 119-128.

Schess, Nancy B. “Then and Now: How Technology Has Changed the Workplace”. Hofstra Labor \& Employment Law Journal. 30/2 (2013): 435-458.

Schulte, Julian, Katharina D. Schlicher ve Günter W. Maier, "Working Everywhere and Every Time? - Chances and Risks in Crowdworking and Crowdsourcing Work Design". Gruppe. Interaktion. Organisation. Zeitschrift für Angewandte Organisationspsychologie. 51 (2020): 59-69.

Serfling, Oliver. Crowdworking Monitor Nr. 1, Bundesministerium Für Arbeit und Soziales, 2018.

Steinberger, Ben Z. "Redefining Employee in the Gig Economy: Shielding Workers from the Uber Model”. Fordham Journal of Corporate and Financial Law. 23/2 (2018): 577-596.

Travis, Michelle A. "Equality in the Virtual Workplace". Berkeley Journal of Employment and Labor Law. 24/2 (2003): 283-376.

Yorğun, Sayım. Ekonomik Politikalar ve Endüstri İlişkilerinin Geleceği. İstanbul: Beta Basim, 2019. 